\title{
Pengaruh Pelatihan dan Motivasi Terhadap Kinerja Pengajar Melalui Mediasi Kompetensi
}

\author{
Asep Hendiawan ${ }^{a^{*}}$ \\ *AKMI Suaka Bahari \\ a*Email: asephendiawan@gmail.com
}

\begin{abstract}
ABSTRAK
Penelitian ini bertujuan untuk menguji dan menganalisis pengaruh pelatihan terhadap minat instruktur di Politeknik Ilmu Pelayaran Semarang. Untuk menguji dan menganalisis pengaruh motivasi terhadap minat pengajar Politeknik Ilmu Pelayaran Semarang. Untuk menguji dan menganalisis pengaruh pelatihan terhadap kinerja instruktur di Politeknik Ilmu Pelayaran Semarang. Untuk menguji dan menganalisis pengaruh motivasi terhadap kinerja instruktur di Politeknik Ilmu Pelayaran Semarang. Untuk menguji dan menganalisis pengaruh minat terhadap kinerja instruktur Politeknik Ilmu Pelayaran Semarang. Populasi dalam penelitian ini adalah instruktur Politeknik Ilmu Pelayaran Semarang yang berjumlah 106 orang. Pengambilan sampel menggunakan teknik sensus yaitu semua populasi dijadikan sampel sehingga jumlah sampel sebanyak 106 orang. Adapun data diperoleh dengan kuesioner dengan analisis data menggunakan regresi linier.

Berdasarkan penelitian yang telah dilakukan maka dapat diperoleh kesimpulan sebagai berikut Pelatihan berpengaruh terhadap minat. Motivasi berpengaruh pada minat. Pelatihan berpengaruh pada kinerja instruktur. Motivasi berpengaruh terhadap kinerja instruktur. Minat berpengaruh pada kinerja instruktur. Minat tidak mempengaruhi mediasi pengaruh pelatihan terhadap kinerja instruktur. Minat tidak mempengaruhi mediasi, motivasi untuk kinerja instruktur
\end{abstract}

Kata Kunci: pelatihan, motivasi, performa instruktur dan minat

\section{PENDAHULUAN}

Keberadaan sumber daya manusia di dalam suatu organisasi memegang peranan sangat penting. Tenaga kerja memiliki potensi yang besar untuk menjalankan aktivitas organisasi. Potensi setiap sumber daya manusia yang ada dalam organisasi harus dapat dimanfaatkan dengan sebaikbaiknya sehingga mampu memberikan output optimal. Tercapainya tujuan organisasi tidak hanya tergantung pada peralatan modern, sarana dan prasarana yang lengkap, tetapi justru lebih tergantung pada manusia yang melaksanakan pekerjaan tersebut. Keberhasilan suatu organisasi sangat dipengaruhi oleh kinerja individu pegawainya. Kinerja menurut Mangkunegara (2009) sebagai hasil kerja secara kualitas dan kuantitas yang dapat dicapai oleh seseorang dalam melaksanakan tugas sesuai dengan tanggung jawab yang diberikan.

Penelitian sebelumnya mengenai pengaruh pelatihan terhadap kinerja pernah dilakukan oleh Rifki Aditya, Hamidah Nayati Utami dan Ika Ruhana (2015) serta Isa Bharoka Trawardani, Arik Prasetya, Yuniadi Mayowan (2015) yang menghasilkan pelatihan berpengaruh positif dan signifikan terhadap kinerja. Berbeda dengan penelitian yang dilakukan oleh Ita Rahmawati (2010) dan Titin Olga silvia (2013) menunjukkan hasil bahwa pelatihan tidak berpengaruh signifikan terhadap kinerja.

Faktor lain yang mempengaruhi kinerja adalah motivasi. Motivasi merupakan salah satu aspek yang sangat penting dalam menentukan kinerja karyawan. Tinggi rendahnya kinerja tenaga kerja yang dimiliki sebuah organisasi akan sangat 
dipengaruhi oleh faktor seperti motivasi kerja dari individu karyawan. Menurut Hasibuan (2006) motivasi penting karena motivasi adalah hal yang menyebabkan, menyalurkan, dan mendukung perilaku manusia supaya mau bekerja giat dan antusias mencapai hasil yang optimal.

Motivasi dapat berasal dari dalam diri maupun luar diri seseorang, sebagai contoh motivasi intrinsik jika seseorang berhasil mencapai motivasinya, maka yang bersangkutan cenderung untuk terus termotivasi. Sebaliknya jika seseorang sering gagal mewujudkan motivasinya, maka yang bersangkutan mungkin tetap terus bekerja sampai motivasinya tercapai atau menjadi putus asa yang berakibat langsung kepada kinerja kerja dari karyawan tersebut, sedangkan motivasi ekstrinsik merupakan faktor eksternal di luar karyawan yang dapat mempengaruhi motivasi karyawan. Motivasi sangat mempengaruhi keberhasilan suatu organisasi, terutama dalam usaha untuk meningkatkan kinerja karyawan.

Penelitian mengenai pengaruh motivasi terhadap kinerja pernah dilakukan oleh Agustina Rahmah, Ahmad Alim Bachri dan Anna Nur Faidah (2013), Budi Arniad (2015) dan Siti Munasih (2016) yang menyebutkan bahwa motivasi intrinsik dan ekstrinsik berpengaruh secara positif dan signifikan terhadap kinerja. Berbeda dengan penelitian yang dilakukan oleh Linawati (2014) menunjukkan hasil bahwa motivasi intrinsik tidak berpengaruh signifikan terhadap kinerja dan Maranatha (2014) menunjukkan hasil bahwa motivasi ekstrinsik tidak berpengaruh signifikan terhadap kinerja.

Disamping pelatihan dan motivasi, faktor lain yang mempengaruhi kinerja adalah kompetensi. Profesionalisme kinerja pengajar sangat terkait dengan kemampuan mewujudkan atau mengaktualisasikan kompetensi yang dipersyaratkan bagi setiap pengajar. Kompetensi adalah spesifikasi dari pengetahuan, keterampilan dan sikap yang dimiliki seseorang serta penerapannya di dalam pekerjaan sesuai dengan standar kinerja yang dibutuhkan oleh lapangan (Dirjen Dikdasmen, 2004). Kompetensi akan terwujud dalam bentuk penguasaan pengetahuan, keterampilan maupun sikap professional dalam menjalankan tugasnya. Selain itu pengajar hendaknya memiliki kompetensi yang baik, agar dalam menjalankan tugasnya dapat maksimal, seperti yang tertuang dalam PP No. 19 tahun 2005 tentang Standar Nasional Pendidikan menyebutkan bahwa kompetensi yang harus dimiliki pengajar yaitu: kompetensi pedagogik, kompetensi kepribadian, kompetensi sosial dan kompetensi profesional.

Penelitian sebelumnya mengenai pengaruh kompetensi terhadap kinerja pernah dilakukan oleh Ali Baba (2012), Muhamad Anis dan Sutomo (2015) serta Rifki Aditya, Hamidah Nayati Utami dan Ika Ruhana (2015) yang menghasilkan kompetensi berpengaruh positif dan signifikan terhadap kinerja pegawai. Berbeda dengan penelitian yang dilakukan oleh Sri Langgeng Ratnasari (2016) menunjukkan hasil bahwa kompetensi tidak berpengaruh signifikan terhadap kinerja.

Dengan pelatihan yang berkualitas serta motivasi intrinsik dan ekstrinsik yang tinggi serta didukung dengan kompetensi kerja yang tinggi, maka akan dapat meningkatkan kinerja. Penelitian sebelumnya mengenai pengaruh motivasi terhadap kompetensi pernah dilakukan oleh Nirmala Ahmad Ma'ruf dan Siswanto (2010) yang menghasilkan motivasi berpengaruh positif dan signifikan terhadap kompetensi. Penelitian sebelumnya mengenai pengaruh pelatihan terhadap kompetensi pernah dilakukan oleh Rifki Aditya, Hamidah Nayati Utami dan Ika Ruhana (2015) serta Citra Rahayu Ningsih (2017) yang menghasilkan pelatihan berpengaruh positif dan signifikan terhadap kompetensi kerja pegawai. Berbeda dengan penelitian yang dilakukan oleh Putu Ifo Yuda Wisastra dan Ella Jauvani Sagala (2016) berpengaruh 
tidak signifikan terhadap kompetensi kerja pegawai.

Kajian penelitian mengenai pengaruh pelatihan dan motivasi terhadap kinerja dosen dengan dimediasi dengan kompetensi akan dilakukan pada Dosen di Politeknik Ilmu Pelayaran Semarang. Politeknik Ilmu Pelayaran Semarang adalah salah satu Lembaga Pendidikan Maritim negeri dibawah naungan Kementerian Perhubungan dan satusatunya yang berada di Jawa Tengah, yang berlokasi di Jalan Singosari 2a Semarang dengan tugas pokok membina dan mencetak lulusan perwira-perwira kapal niaga, baik kapal-kapal milik Negara maupun kapal-kapal swasta.

Sejak diberlakukan STCW 2010 Amandemen Manila yang diberlakukan pada 1 Januari 2017 maka para pelaut diharuskan meng-update ijazahnya, juga beberapa Sertifikat kepelautan di Unit Pelayanan Teknis (UPT) Pendidikan dan latihan Badan Pengembangan Sumber Daya Manusia (BPSDM) Kementrian perhubungan. Untuk terlaksananya updating bahkan upgrading banyaknya para pelaut yang mengikuti Diklat di samping itu kekurangan tenaga kerja profesional pengajar kepelautan. Politeknik Ilmu Pelayaran Semarang yang termasuk Diklat UPT BPSDM Kementerian Perhubungan dalam hal ini masih memerlukan tenaga Pengajar Profesional juga setelah di berlakukannya BLU adalah instansi di lingkungan pemerintah yang dibentuk memberikan pelayanan kepada masyarakat berupa penyediaan barang dan jasa yang dijual tanpa mengutamakan mencari keuntungan dan dalam melakukan kegiatannya didasarkan pada prinsip efisiensi dan produktifitas maka dari itu manajemen Politeknik Ilmu Pelayaran Semarang memutuskan untuk memenuhi kebutuhan pengajar profesional dengan merekrut beberapa pelaut yang sudah berpengalaman. Untuk mengisi kekosongan yang selama ini terjadi.
Ada beberapa diklat kepelautan yang diadakan di Politeknik Ilmu Pelayaran Semarang antara lain D4 (Diploma 4), DP III (Diklat Pembentukan) DP I (Diklat Pelaut tingkat I) sampai DP IV (Diklat Pelaut tingkat IV) serta short course. Mengingat keterbatasan pengajar dari para Pegawai Negeri Sipil (PNS) juga tidak adanya lagi penerimaan PNS sekarang ini.

Dikarenaken para pegawai itu masih baru dan harus beradaptasi dengan lingkungan kerja yang baru maka manajemen memberikan beberapa Pelatihan-pelatihan dalam mengajar terutama bagi pengajar di Lingkungan BPSDM Perhubungan yang berkiblat pada International Maritime Organization (IMO) Organisasi Maritim Dunia di mana para pengajar harus mempunyai sertifikat mengajar seperti Training Of Trainer (TOT) Model Course 6.09 untuk pengajar ataupun Training of Examination (TOE) Model Course 3.12 untuk penguji pelatihan ini sesuai dengan IMO Model Course pada organisasi maritim dunia lainnya di instansi dalam maupun luar negeri untuk melaksanakan pembelajaran dan pengujian pada materi tertentu di bidang kepelautan serta dibuktikan dengan sertifikat yang telah diregistrasi dan diakui oleh Direktorat Jenderal Perhubungan Laut dengan berlandaskan:

1. Peraturan Menteri (PM) 70 tahun 2013 tentang Pendidikan dan Pelatihan, Sertifikasi serta Dinas Jaga Laut dan Konvesi International Standard of Training, Certification and Watchkeeping for seafarers (STCW) 1978 dan amandemennya.

2. Undang- Undang nomer 17 tahun 2008 tentang pelayaran (Lembaran Negara Republik Indonesia Tahun 2008 Nomer 64, Tambahan Lembaran Negara Republik Indonesia Nomer 4849)

3. Keputusan Presiden Nomer 60 Tahun 1986 tentang Pengesahan InternationalStandard of Training, Certification and Watchkeeping for seafarers (STCW) 1978. 
Tujuan dari penelitian ini antara lain adalah:

1. Untuk menguji dan menganalisis pengaruh pelatihan terhadap kompetensi pengajar di Politeknik Ilmu Pelayaran Semarang.

2. Untuk menguji dan menganalisis pengaruh motivasi terhadap kompetensi pengajar Politeknik Ilmu Pelayaran Semarang.

3. Untuk menguji dan menganalisis pengaruh pelatihan terhadap kinerja pengajar di Politeknik Ilmu Pelayaran Semarang.

4. Untuk menguji dan menganalisis pengaruh motivasi terhadap kinerja pengajar di Politeknik Ilmu Pelayaran Semarang.

5. Untuk menguji dan menganalisis pengaruh kompetensi terhadap kinerja pengajar Politeknik Ilmu Pelayaran Semarang.

\section{METODE}

Populasi menurut Sutrisno Hadi (2006) adalah sekumpulan dari seluruh elemenelemen yang dalam hal ini diartikan sebagai obyek penelitian. Adapun populasi dalam penelitian ini adalah pengajar Politeknik Ilmu Pelayaran Semarang yang berjumlah 106 orang. Dalam penelitian ini menggunakan data primer. Data primer merupakan data yang bersumber dari tangan pertama, data yang diambil menggunakan cara kuesioner. Tahap pengolahan data meliputi:

a. Editing: proses yang dilakukan setelah data terkumpul melihat apakah jawaban pada kuesioner telah lengkap.

b. Coding: proses pemberian kode tertentu terhadap aneka ragam jawaban di kuesioner untuk dikelompokkan dalam kategori yang sama.

c. Pemberian Skor: menggunakan skala Likert dengan menggunakan tujuh kategori.

d. Tabulasi yaitu pengelompokkan atas jawaban yang diteliti dan teratur kemudian dihitung dan dijumlahkan sampai terwujud dalam bentuk tabel yang berguna.

\section{HASIL DAN PEMBAHASAN}

Dalam pengolahan data dilakukan uji regresi dalam dua tahap.

a. Tahap I

Tahap I merupakan analisis regresi ganda dengan variable bebas pelatihan dan motivasi dengan variabel terikat adalah kompetensi. Dalam analisis ini diperoleh standardized coefisien yang menunjukkan koefisien jalurnya seperti ditunjukkan pada tabel 1. Pada tabel di atas hasil regresi persamaan I Pengaruh pelatihan dan motivasi terhadap kompetensi diketahui sebagai berikut :

$\mathrm{Y} 1=0,278 \mathrm{X} 1+0,397 \mathrm{X} 2$

Keterangan :

$\mathrm{Y} 1$ = Kompetensi

$\mathrm{X} 1$ = Pelatihan

X2 = Motivasi

Berdasarkan persamaan tersebut dapat diketahui hasil hipotesis bahwa hasil koefisien regresi pelatihan 0,278 dan nilai signifikan sebesar $0,004<$ 0,05 . Berdasarkan hasil pengujian dapat disimpulkan bahwa hipotesis pertama (H1): pelatihan berpengaruh terhadap kompetensi pengajar di Politeknik Ilmu Pelayaran Semarang terbukti atau dapat diterima.

Hasil koefisien regresi motivasi 0,397 dan nilai signifikan sebesar 0,000 $<0,05$. Berdasarkan hasil pengujian dapat disimpulkan bahwa hipotesis kedua (H2): motivasi berpengaruh terhadap kompetensi pengajar di Politeknik Ilmu Pelayaran Semarang terbukti atau dapat diterima.

b. Tahap 2

Pengujian tahap 2 ini digunakan untuk mengetahui pengaruh pelatihan, motivasi dan kompetensi terhadap kinerja pengajar.

Tabel 1. Hasil Regresi Pengaruh pelatihan dan motivasi terhadap kompetensi. 
ISSN : 2087-3050

e-ISSN : 2722-0621

\begin{tabular}{|c|c|c|c|c|c|}
\hline \multirow[b]{2}{*}{ Model } & \multicolumn{2}{|c|}{$\begin{array}{l}\text { Unstandardized } \\
\text { Coefficients }\end{array}$} & \multirow{2}{*}{\begin{tabular}{|l|}
$\begin{array}{l}\text { Standardized } \\
\text { Coefficients }\end{array}$ \\
Beta \\
\end{tabular}} & \multirow[b]{2}{*}{$\mathrm{t}$} & \multirow[b]{2}{*}{ Sig. } \\
\hline & $B$ & Std. Error & & & \\
\hline $\begin{array}{l}1 \text { (Consta } \\
\text { nt) }\end{array}$ & $\begin{array}{l}9.64 \\
8\end{array}$ & 4.973 & & 1.940 & .055 \\
\hline $\begin{array}{l}\text { Pelatiha } \\
\mathrm{n}\end{array}$ & .248 & 085 & .278 & 2.927 & .004 \\
\hline Motivasi & .473 & 113 & .397 & 4.174 & .000 \\
\hline
\end{tabular}

Tabel 2. Hasil Regresi Pengaruh pelatihan, motivasi dan kompetensi terhadap kinerja pengajar

\begin{tabular}{|l|r|r|c|c|c|}
\hline \multirow{2}{*}{ Model } & \multicolumn{2}{|c|}{$\begin{array}{l}\text { Unstandardized } \\
\text { Coefficients }\end{array}$} & $\begin{array}{c}\text { Standardized } \\
\text { Coefficients }\end{array}$ & $\mathrm{t}$ & Sig. \\
\cline { 2 - 6 } & $\mathrm{B}$ & $\begin{array}{r}\text { Std. } \\
\text { Error }\end{array}$ & Beta & & \\
\hline 1 (Constant) & 40.675 & 5.105 & & 7.967 & .000 \\
Pelatihan & .184 & .089 & .177 & 2.066 & .041 \\
Motivasi & .380 & .124 & .273 & 3.072 & .003 \\
$\begin{array}{l}\text { Kompeten } \\
\text { si }\end{array}$ & .479 & .099 & .411 & 4.824 & .000 \\
\hline
\end{tabular}

Pada tabel 2. Hasil analisis regresi persamaan II pengaruh pelatihan, motivasi dan kompetensi terhadap kinerja pengajar dapat diketahui persamaan regresi sebagai berikut :

$\mathrm{Y} 2=0,177 \mathrm{X} 1+0,273 \mathrm{X} 2+0,411 \mathrm{Y} 1$

$\mathrm{Y} 1$ = Kompetensi

$\mathrm{Y} 2$ = Kinerja Pengajar

$\mathrm{X} 1$ = Pelatihan

X2 = Motivasi

Berdasarkan persamaan tersebut dapat diketahui hasil hipotesis :

1. Hasil koefisien regresi pelatihan 0,177 dan nilai signifikan sebesar $0,041<$ 0,05 . Berdasarkan hasil pengujian dapat disimpulkan bahwa hipotesis ketiga (H3) : pelatihan berpengaruh terhadap kinerja pengajar di Politeknik Ilmu Pelayaran Semarang terbukti atau dapat diterima.

2. Hasil koefisien regresi motivasi 0,273 dan nilai signifikan sebesar $0,003<$ 0,05. Berdasarkan hasil pengujian
Dinamika Bahari

Vol.1 No.2 Edisi Oktober 2020 : 79-89

dapat disimpulkan bahwa hipotesis keempat (H4) : motivasi berpengaruh terhadap kinerja pengajar di Politeknik Ilmu Pelayaran Semarang terbukti atau dapat diterima.

3. Hasil koefisien regresi kompetensi 0,411 dan nilai signifikan sebesar 0,000 $<0,05$. Berdasarkan hasil pengujian dapat disimpulkan bahwa hipotesis kelima (H5) : kompetensi berpengaruh terhadap kinerja pengajar di Politeknik Ilmu Pelayaran Semarang terbukti atau dapat diterima.

c. Uji Intervening

Pengaruh Pelatihan Terhadap Kinerja Mengajar Dengan Kompetensi Sebagai Variabel Intervening seperti ditunjukkan pada gambar 1.

Berdasarkan gambar 1 dapat diketahui sebagai berikut:

1. Pengaruh langsung $=0,177$

2. Pengaruh tidak langsung

$$
\begin{aligned}
& =\beta 1 \times \beta 5 \\
& =0,278 \times 0,411 \\
& =0,114
\end{aligned}
$$

Berdasarkan jalur model yang diajukan dalam teori dinyatakan bahwa pelatihan mempunyai hubungan langsung dengan kinerja pengajar ( $\beta 3$ ) sebesar 0,177 dan pelatihan mempunyai hubungan tidak langsung dengan kinerja pengajar melalui intervening kompetensi ( $\beta 1$ X $\beta 5)$ sebesar 0,114 . Berdasarkan hasil tersebut di atas maka dapat disimpulkan bahwa pengaruh tidak langsung sebesar $0,114<$ pengaruh langsung 0,177 maka dikatakan kompetensi tidak mengintervening pelatihan terhadap kinerja pengajar sehingga pelatihan lebih efektif berpengaruh langsung terhadap kinerja daripada melalui kompetensi. 


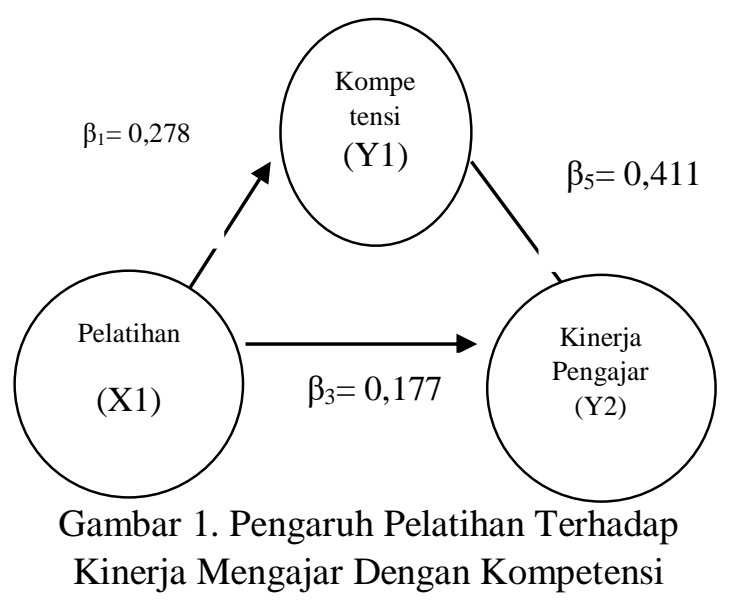

Berdasarkan jalur model yang diajukan dalam teori dinyatakan bahwa pelatihan mempunyai hubungan langsung dengan kinerja pengajar $\left(\beta_{3}\right)$ sebesar 0,177 dan pelatihan mempunyai hubungan tidak langsung dengan kinerja pengajar melalui intervening kompetensi $\left(\beta_{1} \mathrm{X} \beta_{5}\right)$ sebesar 0,114 . Berdasarkan hasil tersebut di atas maka dapat disimpulkan bahwa pengaruh tidak langsung sebesar $0,114<$ pengaruh langsung 0,177 maka dikatakan kompetensi tidak mengintervening pelatihan terhadap kinerja pengajar sehingga pelatihan lebih efektif berpengaruh langsung terhadap kinerja daripada melalui kompetensi.

2. Pengaruh Motivasi Terhadap Kinerja Pengajar Dengan Kompetensi Sebagai Variabel Intervening. Berdasarkan gambar 2. Dapat diketahui sebagai berikut :

1. Pengaruh langsung $=0,273$

2. Pengaruh tidak langsung

$=\beta_{2} \times \beta_{5}$

$=0,397 \times 0,411$

$=0,163$

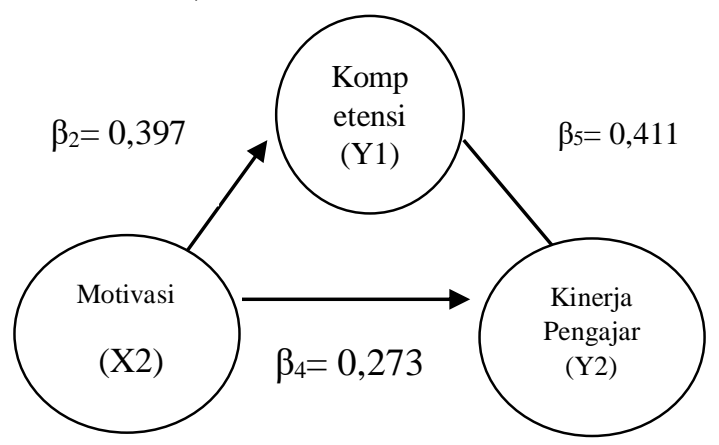

Gambar 2. Pengaruh Motivasi

Terhadap Kineria Pengajar
Berdasarkan jalur model yang diajukan dalam teori dinyatakan bahwa motivasi mempunyai hubungan langsung dengan kinerja pengajar $\left(\beta_{4}\right)$ sebesar 0,273 dan motivasi mempunyai hubungan tidak langsung dengan kinerja pengajar melalui intervening kompetensi $\left(\beta_{2} \mathrm{X} \beta_{5}\right)$ sebesar 0,163 . Berdasarkan hasil tersebut di atas maka dapat disimpulkan bahwa pengaruh tidak langsung sebesar 0,163 < pengaruh langsung 0,273 maka dikatakan kompetensi tidak mengintervening motivasi terhadap kinerja pengajar sehingga motivasi lebih efektif berpengaruh langsung terhadap kinerja pengajar daripada melalui kompetensi.

Hasil penelitian yang dilakukan untuk mengetahui pengaruh pelatihan dan motivasi terhadap kinerja pengajar dengan dimediasi kompetensi pada pengajar Politeknik Ilmu Pelayaran Semarang adalah sebagai berikut:

1. Pengaruh pelatihan dan motivasi terhadap kompetensi

a. Pengaruh pelatihan terhadap kompetensi

Berdasarkan hasil pengujian dapat disimpulkan bahwa hipotesis pertama $\left(\mathrm{H}_{1}\right) \quad$ : pelatihan berpengaruh terhadap kompetensi pengajar di Politeknik Ilmu Pelayaran Semarang terbukti atau dapat diterima. Hasil penelitian ini sama dengan penelitian yang dilakukan oleh Aditya, Utami dan Ruhana (2015) serta Ningsih (2016) yang menghasilkan pelatihan berpengaruh positif dan signifikan terhadap kompetensi.

b. Pengaruh motivasi terhadap kompetensi

Berdasarkan hasil pengujian dapat disimpulkan bahwa hipotesis kedua $\left(\mathrm{H}_{2}\right)$ : motivasi berpengaruh terhadap kompetensi pengajar di Politeknik Ilmu Pelayaran Semarang terbukti atau dapat diterima. Hasil penelitian ini sama dengan penelitian yang dilakukan oleh Ma'ruf dan Siswanto (2010) 
serta Satria dan Kuswara (2013) yang menghasilkan motivasi berpengaruh positif dan signifikan terhadap kompetensi.

2. Pengaruh pelatihan, motivasi dan kompetensi terhadap kinerja pengajar

a. Pengaruh komitmen organisasi terhadap kepuasan kerja

Berdasarkan hasil pengujian dapat disimpulkan bahwa hipotesis ketiga $\left(\mathrm{H}_{3}\right)$ : pelatihan berpengaruh terhadap kinerja pengajar di Politeknik Ilmu Pelayaran Semarang terbukti atau dapat diterima. Hasil penelitian ini sama dengan penelitian terdahulu yang dilakukan oleh Aditya, Utami dan Ruhana (2015) serta Trawardani, Prasetya dan Mayowan (2015) yang menghasilkan pelatihan berpengaruh positif dan signifikan terhadap kinerja.

b. Pengaruh motivasi terhadap kinerja pengajar

Berdasarkan hasil pengujian dapat disimpulkan bahwa hipotesis keempat $\left(\mathrm{H}_{4}\right)$ : motivasi berpengaruh terhadap kinerja pengajar di Politeknik Ilmu Pelayaran Semarang terbukti atau dapat diterima. Hasil penelitian ini sama dengan penelitian terdahulu yang dilakukan oleh Lee dan Kulviwat (2008), Rahmah, Bachri dan Faidah (2013), Arniad (2015) dan Munasih (2016) yang menyebutkan bahwa motivasi intrinsik dan ekstrinsik berpengaruh secara positif dan signifikan terhadap kinerja.

c. Pengaruh motivasi terhadap kepuasan kerja

Berdasarkan hasil pengujian dapat disimpulkan bahwa hipotesis kelima $\quad\left(\mathrm{H}_{5}\right)$ : kompetensi berpengaruh terhadap kinerja pengajar di Politeknik Ilmu Pelayaran Semarang terbukti atau dapat diterima. Hasil penelitian ini sama dengan penelitian terdahulu yang dilakukan oleh Baba (2012),
Anis dan Sutomo (2015) serta Aditya, Utami dan Ruhana (2015) yang menghasilkan kompetensi berpengaruh positif dan signifikan terhadap kinerja pegawai.

3. Pengaruh Pelatihan Dan Motivasi Terhadap Kinerja Pengajar Dengan Kompetensi Sebagai Variabel Intervening

a. Pengaruh Pelatihan Terhadap Kinerja Pengajar Dengan Kompetensi Sebagai Variabel Intervening

Berdasarkan jalur model yang diajukan dalam teori dinyatakan bahwa pelatihan mempunyai hubungan langsung dengan kinerja pengajar $\left(\beta_{3}\right)$ dan pelatihan mempunyai hubungan tidak langsung dengan kinerja pengajar melalui intervening kompetensi $\left(\beta_{1}\right.$ $X \beta_{5}$ ). Berdasarkan hasil tersebut di atas maka dapat disimpulkan bahwa pengaruh tidak langsung lebih kecil dibandingkan pengaruh langsung, maka dikatakan kompetensi tidak mengintervening pelatihan terhadap kinerja pengajar sehingga pelatihan lebih efektif berpengaruh langsung terhadap kinerja pengajar daripada melalui kompetensi.

b. Pengaruh Motivasi Terhadap Kinerja Pengajar Dengan Kompetensi Sebagai Variabel Intervening

Berdasarkan jalur model yang diajukan dalam teori dinyatakan bahwa motivasi mempunyai hubungan langsung dengan kinerja pengajar $\left(\beta_{4}\right)$ dan motivasi mempunyai hubungan tidak langsung dengan kinerja pengajar melalui intervening kompetensi $\left(\beta_{2}\right.$ $\mathrm{X} \beta_{5}$ ). Berdasarkan hasil tersebut di atas maka dapat disimpulkan bahwa pengaruh tidak langsung lebih kecil dibandingkan pengaruh langsung, maka dikatakan kompetensi tidak mengintervening motivasi terhadap kinerja pengajar sehingga motivasi lebih efektif 
berpengaruh langsung terhadap kinerja pengajar daripada melalui kompetensi.

\section{SIMPULAN}

Berdasarkan penelitian mengenai pengaruh pelatihan dan motivasi terhadap kinerja pengajar dengan dimediasi kompetensi pada pengajar Politeknik Ilmu Pelayaran Semarang dapat diperoleh kesimpulan sebagai berikut :

a. Pelatihan berpengaruh terhadap kompetensi.

b. Motivasi berpengaruh terhadap kompetensi.

c. Pelatihan berpengaruh terhadap kinerja pengajar.

d. Motivasi berpengaruh terhadap kinerja pengajar.

e. Kompetensi berpengaruh terhadap kinerja pengajar.

f. Kompetensi tidak memediasi pengaruh pelatihan terhadap kinerja pengajar

g. Kompetensi tidak memediasi pengaruh motivasi terhadap kinerja pengajar

\section{DAFTAR PUSTAKA}

Abidin, Nur, 2009, Pengaruh Kepuasan, Motivasi dan Kedisiplinan Kerja Terhadap Kinerja Pegawai di Lingkungan Kantor Wilayah Departemen Agama Provinsi Jawa Tengah, Jurnal Manajemen Universitas Dian Nuswantoro Semarang

Adeyinka Tella, 2007, Work Motivation, Job Satisfation and Organisational Commmitment of Library Personnel in Academic and Research Libraries in Oyo State, Nigeria, Library Philosopy and Practice 2007.

Amran. 2009. "Pengaruh Disiplin Kerja Terhadap Kinerja Pegawai kantor Departemen Sosial Kabupaten Gorontalo". Dalam Jurnal Ichsan Gorontalo, Volume 4 No. 2. Hal
2397-2413. Gorontalo:

Universitas Ichsan Gorontalo

Arifin, N., 2009. Aplikasi Konsep Quality of Work Life dalam Upaya Menumbuhkan Motivasi

Karyawan Berkinerja Unggul, Usahawan, No 10, hal 25-29.

Arikunto, S 2010, 'Prosedur Penelitian Suatu Pendekatan Praktik', PT Rhineka Cipta, Jakarta.

Armanu dan Mardayanti, 2011, Pengaruh Pemberdayaan Psikologi dan Komitmen Afektif terhadap Kepuasan Kerja dan Kinerja Pegawai (Studi Pada Pegawai Dinas Tata Kota dan Pengawas Bangunan Kota Mataram), Jurnal manajemen Universitas Brawijaya Malang

Awaludin, 2016, The Effect of Job Satisfaction, Integrity and Motivation on Performance, Jurnal Manajemen Vol.VI, No.2 Januari 2016

Brahmasari, Ida Ayu dan Suprayetno, 2008. Pengaruh Motivasi Kerja, Kepemimpinan dan Budaya Organisasi terhadap Kepuasan Kerja Karyawan serta Dampaknya pada Kinerja Perusahaan (Studi Kasus pada PT. Pei Hai International Wiratama Indonesia) Jurnal Manajemen dan Kewirausahaan, Vol.10, No. 2: 124-135. Surabaya: Universitas 17 Agustus.

Dwi, Ged, Aditya, 2014, Pengaruh Komitmen Profesional Pada Kepuasan Kerja Auditor Dengan Motivasi Sebagai Variabel Moderating, Menara Ilmu Vol. IX No.42 Nov 2014

Erina, Cut, 2012, Pengaruh Integritas, Objektivitas, Kerahasiaan Dan 
Kompetensi Terhadap Kinerja Aparat Pengawasan Internal Pemerintah (Studi Pada Inspektorat Aceh), Jurnal Bisnis, Volume 8, No 1

Ferdinand, Augusty (2006). Manajemen Pemasaran : Sebuah Pendekatan Strategic, Semarang: BP. Undip

Flippo, Edwin B.(1984). Manajemen Personalia, Edisi Keenam, Terjemahan Moh. Mas'ud, Jakarta: PT. Erlangga.

Ghozali, Imam. 2013. Aplikasi Analisis Multivariate Dengan Program SPSS, Semarang: Badan Penerbit Universitas Diponegoro.

Gibson, J. L., Ivancevich, J. M., \& Donelly, J. H. (1997). Organizations: Behavior, Structure, and Processes, New York: McGraw-Hill.

Hasibuan, Malayu SP, , 2007, Manajemen Sumber Daya Manusia, Edisi Revisi, Bumi Aksara, Jakarta

Hermansyah dan Sri Indarti, 2015, Pengaruh Motivasi Dan Disiplin Kerja Terhadap Kepuasan Dan Kinerja Karyawan PT. Peputra Supra Jaya Pekanbaru, Jurnal Tepak Manajemen Bisnis Vol. VII No. 2 Mei 2015

Husnan. 2007. Manajemen Sumber Daya Manusia untuk Perusahaan. Jakarta: PT. Raja Grafindo Persada.

Husnawati, Ari (2006). Analisis Pengaruh Kehidupan Kerja Terhadap Kinerja Karyawan Dengan Komitmen dan Kepuasan Kerja Sebagai Intervening Variabel, Tesis, Universitas Diponegoro, Semarang.
Kamus Lengkap Bahasa Indonesia Praktis, 2009, Penerbit Refika Aditama, Bandung

Koesmono, 2005, Pengaruh Kompensasi dan Karakteristik Pekerjaan Terhadap Kinerja, Wacana, Vol. 4 No. 1 Juli 2000, Surabaya

Kristianto, Dian, Suharnomo, Intan Ratnawati, 2011, Pengaruh Kepuasan Kerja Terhadap Kinerja Karyawan Dengan Komitmen Organisasional Sebagai Variabel Intervening (Studi Pada RSUD Tugurejo Semarang), Jurnal Ekonomi Universitas Diponegoro Semarang.

Luthans, F.(2006). Perilaku Organisasi, Edisi Sepuluh, Yogyakarta : Andi Offset

Mahardhika, Rangga, Djamhur Hamid dan Ika Ruhana, 2013, Pengaruh Motivasi Kerja Terhadap Kinerja Karyawan (Survei Karyawan Pada PT. Axa Financial Indonesia Sales Office Malang), Jurnal Ilmu Administrasi, Universitas Brawijaya Malang

Mangkunegara, 2009, Perilaku dan Budaya Organisasi, Penerbit Refika Aditama, Bandung.

Mardiono, Dian dan Supriyatin, 2014, Pengaruh Motivasi Dan Disiplin Kerja Terhadap Kepuasan kerja Karyawan, Jurnal Ilmu \& Riset Manajemen Vol. 3 No. 3 (2014)

Maryoto, 2000, Manajemen Sumber Daya Manusia (Manajemen Kepegawaian). Cetakan ke 8. Bandung : Mandar Maju

$$
\begin{array}{lrr}
\text { Murty dan } & \text { Hudiwinarsih, } \\
\text { 2012,Pengaruh } & \text { Kompensasi, } \\
\text { Motivasi Dan } & \text { Komitmen } \\
\text { Organisasional } & \text { Terhadap Kinerja }
\end{array}
$$


Karyawan Bagian Akuntansi (Studi Kasus Pada Perusahaan Manufaktur di Surabaya), The Indonesian Accounting Review Volume 2, No. 2, July 2012, pages $215-228$

Peraturan Pemerintah Republik Indonesia Nomor 37 Tahun 2009 tentang Dosen

Prabu, Anwar, 2005, Manajemen Sumber Daya Manusia, Andi Offset, Yogyakarta

Praja, Ega, Rimata, 2014, Pengaruh Komitmen Organisasi Dan Motivasi Kerja Terhadap Kepuasan Kerja Karyawan PT. Pos Indonesia Yogyakarta

Prasetyo dan Suwarno, 2014, Pengaruh Integritas Perilaku Terhadap Keuasan Kerja Dengan Intervening Motivasi (Studi pada Kantor Akuntan Publik di Jawa Tengah), Seminar Nasional dan The 3rd Call for Syariah Paper

Pratiwi, Kurniasari dan Fathul Himam. (2014). Pengaruh Kualitas Kehidupan Kerja Ditinjau dari Kepuasan Kerja dan Persepsi Terhadap Kinerja. Jurnal Psikologi Undip, Vol.13 No.1, hal 42-49.

Prawani, Dwi Sri Redjeki dan Jefri Heridiansyah, 2013.Memahami Sebuah Konsep Integritas.Jurnal Stie Semarang, Vol 5, No.3, Edisi Oktober2013 (ISSN : 2252-7826).

Pricilya. Wuysang dan Hendra Tawas, 2016, Pengaruh Disiplin Kerja, Perilaku Kepemimpinan Dan Motivasi Kerja Terhadap Kepuasan Kerja dan Kinerja Karyawan KFC Bahu Mall Manado Jurnal Berkala Ilmiah
Efisiensi Volume 16 No. 01 Tahun 2016

Pusdiklatwas BPKP. 2008. Kode Etik dan Standar Audit. Edisi Kelima.

Rakasiwi, Galih, 2014, Pengaruh Motivasi, Kepuasan Kerja, Dan Disiplin Kerja Terhadap Kinerja Pegawai (Studi Empiris Pada Satuan Polisi Pamong Praja Kabupaten Karanganyar), Jurnal Ekonomi dan Bisnis Universitas Muhammadiyah Surakarta

Robbins, S. P. 2006. Prinsip-Prinsip Perilaku Organisasi (Alih Bahasa oleh Halida dan Dewi Sartika), Edisi Kelima, Erlangga, Jakarta.

Sagala, 2009, Manajemen Sumber Daya Manusia, Jakarta: PT. Raja Grafindo Persada.

Simamora, Henry, 2007, Sumber Daya Manusia. STIE. Yogyakarta.

Soejono, 2006, Manajemen Sumber Daya Manusia, Andi Offset, Yogyakarta

Sukiman, 2015, Pengaruh Modal Psikologi Dan Motivasi kerja Terhadap Kinerja Pegawai Melalui Kepuasan Kerja Dan Komitmen Organisasional (Studi BPTIKP Dinas Pendidikan Provinsi Jawa Tengah), Naskah Publikasi Fakultas Ekonomi Dan Bisnis Universitas Diponegoro Semarang

Sukriah, Ika. 2009. "Pengaruh Pengalaman Kerja, Independensi, Obyektifitas, Integritas, dan Kompetensi terhadap Kualitas Hasil Pemeriksaan". Jurnal, Simposium Nasional Akuntansi (SNA) 12. Palembang.

Suprihantono, 2008, Pengaruh Kompensasi dan Karakteristik 
Pekerjaan Terhadap Kepuasan Kerja, Wacana, Vol. 4 No. 1 Juli 2000, Surabaya

UU Nomor 14 Tahun 2005 tentang Guru dan Dosen,

Yakin, Handoko dan Sutrisno (2013), Pengaruh Implementasi Kebijakan, Karakteristik Individu, Karakteristik Organisasi Terhadap Motivasi Kerja Dan Kinerja Sekretaris Desa Di Kabupaten Mojokerto, Jurnal Administrasi Publik Juni 2013, Vol. 11, No. 1, Hal. $129-145$

Yulianti dan Wuryanti, 2015 Pengaruh Integritas Perilaku Terhadap Keuasan Kerja Dengan Intervening Motivasi (Studi BLHKP, BKPPD dan BPMP
Provinsi Sulawesi Tenggara), Jurnal ISSN Vol. 2 Edisi Mei 2015

Yusnaena dan Syahril, 2013, Pengaruh Integritas Terhadap Kepuasan Kerja Pada Sekretariat Daerah Kabupaten Pesisir Selatan, Menara Ilmu Vol. IX No.42 Nov 2013

Zahra, Elvira, 2011, Pengaruh Integritas Terhadap Kepuasan Kerja PT. Pusri Palembang, Jurnal Ilmiah Orasi Bisnis - ISSN: 2085-1375 Edisi Ke-VI, November 2011, Jurnal Ekonomi Manajemen Universitas Negeri Yogyakarta

Zesbendri dan Ariyanti, 2010, Pengaruh Disiplin Kerja Terhadap Kinerja Pegawai Pada Pegawai Kantor Pusat Statistik Kabupaten Bogor, Jurnal Manajemen STIE IPWIJA 